\title{
Paternal engagement during childbirth depending on the manner of their preparation
}

\author{
Urszula Sioma-Markowska ${ }^{1}$, Ryszard Poręba ${ }^{2}$, Mariola Machura ${ }^{1}$, Violetta Skrzypulec-Plinta ${ }^{1}$ \\ 'School of Health Sciences in Katowice, Medical University of Silesia, Katowice, Chair of Woman's Health, \\ Department of Nursing in Gynecology and Obstetrics, Katowice, Poland \\ ${ }^{2}$ Department of Gynecology and Obstetrics, Specialist Teaching Hospital in Tychy, Poland
}

\begin{abstract}
Objectives: The analysis of the forms of paternal activity depending on the manner of their preparation, including stages of labor.

Material and methods: A prospective survey-based study involved 250 fathers who participated in their child's birth. The fathers included in the study were present during all stages of family-assisted natural labor. The study was conducted one day after childbirth with the use of a survey prepared by the authors. Statistical calculations were conducted using the Statistica PL software. The frequency of individual qualitative features (non-measurable) was assessed by means of a non-parametric $X^{2}$ (chi-squared) test. The statistical significance level was $p<0.05$.

Results: A half of the fathers included in the study (52.4\%) participated in childbirth with no prior preparation. The dominant form of preparation involved self-education from books, magazines and the Internet (24\%). $23.6 \%$ of fathers participated in ante-natal classes. The study demonstrated that fathers prepared for childbirth in ante-natal classes more often engaged in the supportive role, provided nursing care and carried out instrumental monitoring during each stage of childbirth.

Conclusions: The fathers prepared for childbirth in ante-natal classes more often engage in the supportive role, provide nursing care and carry out instrumental control during each stage of childbirth. Ante-natal classes should be promoted as an optimal form of preparation for active participation in childbirth. Moreover, other forms of paternal ante-natal education as well as continued education in a delivery room should be developed.
\end{abstract}

Key words: family-assisted childbirth, preparation for childbirth, participation of father

Ginekologia Polska 2016; 87, 9: 639-643

\section{INTRODUCTION}

The contemporary model of care over a woman in labor enables co-participation of the child's father in birth and is consistent with the Regulation of the Polish Minister of Health of 20 September 2012 on standards of perinatal health care (Polish Journal of Laws) [1]. Family-assisted childbirth addresses the needs of the family and creates a new dimension of fatherhood [2, 3]. Ante-natal education of both the mother and father in an organized or individual form is the ultimate supplementation of this propagated form of care. The direct contact with paternal problems during childbirth requires an interdisciplinary approach of an obstetrician and midwife, which frequently goes beyond routine obstetric management.

In Polish and international literature, a great emphasis is put on the necessity of paternal preparation to family-assisted childbirth. In order to enable the father to take active part in childbirth, they should not only possess basic knowledge about the physiology of birth, experiences of a woman in labor and child's situation, but also learn about the role he is to perform. When familiarized and prepared for given actions, fathers will feel needed and helpful during labor [4-8].

The best form of preparation is ante-natal classes which include theoretical, physical and mental preparation of mar- 
riages to labor, and put a particular emphasis on antenatal psychology. In a series of classes on psychoprophylaxis, erroneous convictions about childbirth are eliminated and the profound role of the child's father is underlined. The participation of the father during childbirth is a continuation of obstetric psychoprophylaxis [9-11].

Numerous literature reports indicate that fathers prepared in ante-natal classes provide better support. If a father does not participate in ante-natal classes, he should have wide access to information. Without basic knowledge, a mere thought about being present during labor may evoke objections, and the participation during childbirth will be passive with no interest in the course of labor.

\section{OBJECTIVES}

The aim of the paper was to determine a given category of action and detect a relationship and correlation between the form of paternal activity during family-assisted labor and the manner of their preparation, including stages of labor.

\section{MATERIAL AND METHODS}

A prospective survey-based study involved 250 fathers who participated in their child's birth (a natural birth) in the clinical department of the Medical University of Silesia in Tychy, Poland. The study involved fathers who were present during all stages of family-assisted natural labor and remain in matrimony with the child's mother.

The material was analyzed according to the form of preparation to childbirth. The study excluded fathers who were not married, participated in labors concluded with a cesarean section or complicated as well as those who participated only in a given stage of labor and did not answer $100 \%$ of the questions proper in the survey. The surveys were completed on the first day after common childbirth by the father, after being instructed about the aim of the study, manner of providing answers and obtaining consent. The participation in the study was voluntary and anonymous.

The statistical calculations were conducted using the Statistica PL software. For quantitative features, arithmetic means and standard deviations were calculated for each group. For qualitative features, their percentage/numerical distribution was prepared. The frequency of individual qualitative (non-measurable) features was assessed by means of a non-parametric $x^{2}$ (chi-squared) test. The significance level was $p<0.05$.

\section{RESULTS}

The dominant form of preparation for childbirth involved self-education from books, magazines and the Internet (24\%). $23.6 \%$ of fathers participated in ante-natal classes, and $52.4 \%$ of fathers were present during childbirth without prior preparation.

\begin{tabular}{|c|c|c|c|c|}
\hline \multirow{3}{*}{$\begin{array}{l}\text { Level of } \\
\text { preparation }\end{array}$} & \multicolumn{4}{|c|}{ Preparation } \\
\hline & \multicolumn{2}{|c|}{$\begin{array}{l}\text { Common participation } \\
\text { in ante-natal classes }\end{array}$} & \multicolumn{2}{|c|}{ Self-preparation } \\
\hline & $\mathrm{n}$ & $\%$ & $\mathbf{n}$ & $\%$ \\
\hline Very good & 50 & 84.7 & 2 & 3.3 \\
\hline Good & 9 & 15.3 & 34 & 56.7 \\
\hline Sufficient & 0 & 0.0 & 24 & 40.0 \\
\hline Total & 59 & 100.0 & 60 & 100.0 \\
\hline
\end{tabular}

The analysis of the degree of paternal preparation to childbirth based on the form of preparation has shown that, compared with fathers who had prepared themselves individually, those prepared for childbirth during ante-natal classes were more frequently prepared very well (3.3\% vs. $84.7 \%$, respectively) (Tab. 1). These differences are statistically significant $(p<0.05)$.

The range of paternal activity in individual stages of labor is presented in Table 2. An active attitude of the father was mainly manifested by providing emotional support, nursing activities (massaging the lumbosacral region, directing and controlling breath, helping in assuming a comfortable labor position, reminding about relax, helping in water immersion) and instrumental monitoring (listening to the child's heart rate with a detector, assessing the frequency of contractions, help in assuming pushing positions, cutting the umbilical cord) (Tab. 2).

In all stages of labor, fathers were mainly focused on providing psychological support to the woman in labor (96\%, $92 \%$ and $92.8 \%$, respectively). Moreover, during the first stage of labor, fathers were more frequently engaged in nursing activities (76.8\% of fathers gave their wives fluids to drink, $56.8 \%$ helped assume a comfortable labor position, $46.4 \%$ massaged the lumbosacral region, $42.4 \%$ reminded about relax, $41.6 \%$ directed and controlled breathing) than in instrumental monitoring, such as: listening to the child's heart rate with a detector or assessing the frequency of contractions ( $22.4 \%$ and $36 \%$, respectively). During the second stage, however, instrumental monitoring was the prevailing form of activity ( $84 \%$ of fathers cut the umbilical cord, $65.6 \%$ helped assume a pushing position, $59.2 \%$ helped assume a comfortable labor position, $41.6 \%$ controlled breathing). In the third stage and after childbirth, $84.8 \%$ of fathers participated in child examination, $92.8 \%$ supported their wives and stayed with their wives and children for after birth, $27.6 \%$ of fathers helped in the first breastfeeding (Tab. 2).

When analyzing the forms of paternal activity depending on the manner in which the fathers were prepared for childbirth and including stages of labor, it was found that 
Table 2. Range of activities performed by fathers in individual stages of labor

\begin{tabular}{|l|c|c|c|}
\hline \multirow{2}{*}{ Activities performed by the father } & \multicolumn{2}{|c|}{ Stage of labor } \\
\cline { 2 - 3 } & First (\%) & Second (\%) & 92.8 \\
\hline Providing psychological support & 96.0 & 92.0 \\
\hline Massaging the lumbosacral region & 46.4 & 16.8 \\
\hline Directing and controlling breathing & 41.6 & 12.6 \\
\hline Listening to the child's heart rate with a detector & 22.4 & 59.2 \\
\hline Assistance in assuming a comfortable labor position & 56.8 & \\
\hline Assessing the frequency of contractions & 36.0 & 65.6 \\
\hline Assistance in assuming a pushing position & & 84.0 \\
\hline Cutting the umbilical cord & & 6.0 \\
\hline Placing an ID on the child's hand & 42.4 & 23.2 \\
\hline Reminding about relax & 18.4 & 10.0 \\
\hline Assistance in water relaxation (immersion) & 76.8 & 15.0 \\
\hline Handing the woman fluids to drink & & \\
\hline Participation in child examination & & \\
\hline Assistance in the first breast-feeding & & \\
\hline Staying with the wife and child after childbirth $(2 \mathrm{~h})$ & & \\
\hline
\end{tabular}

Table 3. Forms of paternal activity during childbirth depending on their preparation

\begin{tabular}{|c|c|c|c|c|c|}
\hline \multirow{2}{*}{\multicolumn{2}{|c|}{$\begin{array}{l}\text { Form of preparation } \\
\text { Activities }\end{array}$}} & $\begin{array}{l}\text { Ante-natal } \\
\text { classes }\end{array}$ & Self-preparation & $\begin{array}{l}\text { No preparation (instructions } \\
\text { given in the delivery room) }\end{array}$ & \multirow{2}{*}{$\begin{array}{l}\text { Significance level } \\
\text { (chi-squared test) }\end{array}$} \\
\hline & & (\%) & (\%) & (\%) & \\
\hline \multirow{3}{*}{$\begin{array}{l}\text { First } \\
\text { stage of labor }\end{array}$} & Emotional support & 100.0 & 100.0 & 95.9 & $\begin{array}{c}X^{2}=0.67 \\
\text { NS }\end{array}$ \\
\hline & Nursing activities* & 85.7 & 80.0 & 78.3 & $\begin{array}{c}X^{2}=1.89 \\
\text { NS }\end{array}$ \\
\hline & Instrumental monitoring** & 57.1 & 25.0 & 27.5 & $\begin{array}{c}X^{2}=3.32 \\
\text { NS }\end{array}$ \\
\hline \multirow{3}{*}{$\begin{array}{l}\text { Second } \\
\text { stage of labor }\end{array}$} & Emotional support & 100.0 & 90.0 & 91.3 & $\begin{array}{c}X^{2}=2.17 \\
\text { NS }\end{array}$ \\
\hline & Nursing activities* & 57.1 & 25.0 & 26.4 & $\begin{array}{c}X^{2}=2.98 \\
\text { NS }\end{array}$ \\
\hline & Instrumental monitoring** & 66.1 & 60.0 & 62.3 & $\begin{array}{c}X^{2}=2.48 \\
\text { NS }\end{array}$ \\
\hline \multirow{4}{*}{$\begin{array}{l}\text { Third } \\
\text { stage of labor }\end{array}$} & Emotional support & 100.0 & 95.0 & 91.8 & $\begin{array}{c}X^{2}=2.89 \\
\text { NS }\end{array}$ \\
\hline & $\begin{array}{l}\text { Participation in } \\
\text { In child examination }\end{array}$ & 100.0 & 80.0 & 85.8 & $\begin{array}{c}X^{2}=2.13 \\
\text { NS }\end{array}$ \\
\hline & $\begin{array}{l}\text { Holding the child } \\
\text { In their arms }\end{array}$ & 42.9 & 30.0 & 37.3 & $\begin{array}{c}X^{2}=1.94 \\
\text { NS }\end{array}$ \\
\hline & Assistance in breast-feeding & 42.9 & 20.0 & 22.5 & $\begin{aligned} & X^{2}=3,78 \\
& \text { NS }\end{aligned}$ \\
\hline
\end{tabular}

*Massaging the lumbosacral region, directing and controlling breath, helping in assuming a comfortable labor position, reminding about relax, helping in water immersion, handing water; **listening to the child's heartbeat with a detector, assessing contractions, bearing down assistance, cutting the umbilical cord; NS - not significant

the fathers prepared for childbirth in ante-natal classes more often engaged in the supportive role, provided nursing care and carried out instrumental monitoring during each stage of childbirth than fathers in the remaining groups (self-prepared and non-prepared ones) (Tab. 3). These differences are not statistically significant $(p<0.05)$. 


\section{DISCUSSION}

The participation of a close person in childbirth is recommended by the World Health Organization and numerous other academic associations. Studies on paternal experience and their role during contemporary childbirth are conducted not only in European countries. More and more often they are carried out in countries and continents with a different culture or religion [12-16].

The author's own studies are consistent with those reported by other authors and confirm that fathers actively participate in childbirth and women have specific preferences concerning this issue $[9,11,17-19]$. Paternal activity in individual stages of labor mostly involves emotional support for the woman in labor, but also performing nursing activities and instrumental monitoring. The forms of paternal activity have been confirmed by Leavitt, Ip, Johansson et al. and Johannsson et al. [18, 20-22].

Numerous studies underline the role of engagement and participation of the child's father or other close person in labor. Without a doubt, ante-natal classes are a professional manner of common preparation for childbirth and conscious participation in labor. They help create a psychological bond between couples and develop full awareness of labor. Fathers who have been prepared for labor by professional medical staff consciously and actively participate in their child's birth.

A high percentage of fathers (52.4\%) who participated in labor without preparation, which was observed in this study, indicates that ante-natal classes must still be promoted as a professional way of paternal preparation for providing active help and psychological support during labor. Moreover, other forms of paternal ante-natal education as well as continued education in a delivery room should be developed. The dominant form of preparation for labor was self-education (24\%). $23.6 \%$ of fathers participated in ante-natal classes. These data are consistent with those reported by other authors [23].

In the population of fathers investigated in this study, no statistically significant correlations were found between the manner of preparation to family-assisted childbirth and the range of their activity during labor. However, the percentage of cases indicates that fathers prepared for childbirth in ante-natal classes more frequently engaged in their supportive role, nursing and instrumental monitoring during each stage of labor. According to Deave T et al., global research suggests that fathers in many countries feel unprepared for fatherhood. That is why supporting and preparing them for the participation in family-assisted labor and continued care over a newborn child should be the core curriculum of ante-natal classes [24]. Moreover, a lower percentage of fathers prepared for labor experience negative emotions, such as anxiety, irritation and fear, which is another benefit resulting from ante-natal education. The results of $\mathrm{Li} \mathrm{HT}$ et al. confirm this hypothesis [9].

\section{CONCLUSIONS}

Fathers prepared for childbirth in ante-natal classes more often engage in their supportive role, provide nursing care and carry out instrumental monitoring during each stage of childbirth.

Ante-natal classes are a preferred form of ante-natal education in paternal preparation for family-assisted childbirth and conscious fatherhood.

Ante-natal classes should be promoted as an optimal form of preparation for active participation in childbirth, and other forms of paternal pre-natal education as well as continued education in a delivery room should be developed.

\section{Conflict of interest}

No declared.

\section{REFERENCES}

1. Dziennik Ustaw Rzeczpospolitej Polskiej z dnia 4 października 2012 r poz. 1100. Rozporządzenie Ministra Zdrowia z dnia 20 września 2012r. w sprawie standardów postępowania medycznego przy udzielaniu świadczeń zdrowotnych z zakresu opieki okołoporodowej sprawowanej nad kobietą w okresie fizjologicznej ciąży, fizjologicznego porodu, połogu oraz opieki nad noworodkiem.

2. Wagner M. Fish can't see the water: the need to humanize birth. Int J Gynecol Obstet. 2000, 1, 142-145.

3. Laudański T. Modyfikacja środowiska narodzin — potrzeby matki i dziecka a potrzeby nowoczesnego położnictwa. Ginekol Pol. 2001 $72,8,668-672$

4. Ćwiek D, Torbe A, Gutowska-Czajka D, Czajka R. Rola Szkoły Rodzenia i Poradni Porodu Rodzinnego w przygotowaniu rodziców do porodu. Kliniczna Perinatologia i Ginekologia. 2002, supl. 25, 133-138.

5. Kubicki J, Kowalczyk D, Kudaś D. Analiza kliniczna przebiegu 1300 porodów rodzinnych. Ginekol Pol. 2000, 71, 4, 183-186.

6. Olin RM, Faxelid E. Parents' needs to talk about their experiences of childbirth. Scand J Caring Sci. 2003, 17, 2, 153-159.

7. Saisto T, Salmela-Aro K, Nurmi JE, Halmesmaki E. Psychosocial characteristics of women and their partners fering vaginal childbirth. BJOG. 2001, 108, 5, 492-498.

8. Premberg A, Lundberg I. Fathers' experiences of child birth education J Perinat Educ. 2006, 15, 21-28.

9. Li HT, Lin KC, Chang SC, [et al.]. A birth education program for expectant fathers in Taiwan: effects on their anxiety. Birth. 2009, 36, 4 289-296.

10. Labrague LJ, Cariño JR, Catap RC, [et al.]. Exploring First-Time Fathers' Feelings and Experiences during Labor - Delivery of their Partner/Wife. International Journal of Caring Sciences. 2013, 6, 2, 217-226.

11. Sioma-Markowska U, Poręba R, Skrzypulec-Plinta V. The model of active participation of the father in childbirth, based on the preferences of the parturient women. NEL 2015, 36, 4, 374-379.

12. Abushaikha $L$, Massah $R$. The role of the father during child birth: the lived experiences of Arab Syrian parents. Health Care Women Int. 2012, 33, 168-181.

13. Angelova E, Temkina A. The father who participates in childbirth. Anthropol Archeol Eurasia. 2010, 49, 9-43.

14. Kululanga LI, Malata A, Chirwa E, Sundby J. Malawian fathers'views and experiences of attending the birth of their children: a qualitative study. BMC Pregnancy Childbirth. 2012, 12, 141.

15. Kaye DK, Kakaire O, Nakimuli A, [et al.]. Male involvement during pregnancy and childbirth: men's perceptions, practices and experiences during the care for women who developed childbirth complications in Mulago Hospital, Uganda. BMC Pregnancy and Childbirth. 2014, 14, 54.

16. Tehrani SG, Bazzazian S, Nayeri ND. Pregnancy Experiences of First-Time Fathers in Iran: A Qualitative Interview Study. Iran Red Crescent Med J. 2015, 17, e12271. DOI: 10.5812/ircmj.12271. 
17. Bogren Jungmarker $\mathrm{E}$, Lindgren $\mathrm{H}$, Hildingsson I. Playing second fiddle is OK-Swedish fathers' experiences of prenatal care. J Midwifery Womens Health. 2010, 55, 1-10.

18. Ip WY. Chinese husbands' presence during labor: A preliminary study in Hong Kong. Int J Nurs Pract. 2000, 6, 89-96.

19. Sapountzi-Krepia D, Lavdaniti M, Dimitriadou A, [et al.]. Fathers'Feelings and Experience Related to their Wife/Partner's Delivery in Northern Greece. Open Nurs J. 2010, 4, 48-54.

20. Leavitt JW. What do men have to do with it? Fathers and mid-twentieth-century childbirth. Bull Hist Med. 2003, 77, 2, 236-262.
21. Johansson M, Fenwick J, Premberg A. A meta-synthesis of fathers'experiences of their partner's labour and the birth of their baby. Midwifery. 2015, 31, 9-18.

22. Johansson M, Rubertsson C, Rädestad I, Hildingsson I. Childbirth - an emotionally demanding experience for fathers. Sexual \& Reproductive Healthcare. 2012, 3, 11-20.

23. GuzikowskiW, Kowalczyk D, Mączka M. Analiza aktualnych form przygotowania do porodu rodzinnego i tradycyjnego. Kliniczna Perinatologia i Ginekologia. 2004, supl. 1, 71-73.

24. Deave T, Johnson D. The transition to parenthood: what does it mean for fathers? Journal of Advanced Nursing. 2008, 63, 626-633. 